\title{
Pin1: A New Enzyme Pivotal for Protecting Against Alzheimer's Disease
}

\author{
Kazuhiro Nakamura, Suk Ling Ma and Kun Ping Lu \\ Department of Medicine, Beth Israel Deaconess Medical Center \\ Harvard Medical School, Boston
}

USA

\section{Introduction}

Alzheimer's disease (AD) affects more than 35 million people worldwide, and the prevalence of $\mathrm{AD}$ increases with age and doubles every 5 years after the age of 65 (Evans et al., 1989). AD is characterized by intracellular neurofibrillary tangles (NFTs) and extracellular amyloid fibrils composed of amyloid beta peptides (A $\beta$ ). Accordingly, both tau and amyloid have been the targets for development of treatment for AD.

Tau-mediated neurodegeneration may result from the combination of toxic gains-offunction acquired by the aggregates or their precursors and the detrimental effects that arise from the loss of the normal function(s) of tau in the disease state (Ballatore et al., 2007). The toxic gains-of-function includes sequestration of normal tau function by NFTs made of hyperphosphorylated tau. NFTs also become physical obstacles to the transport of vesicles and other cargos (Ballatore et al., 2007). The loss of the normal function of tau includes detachment of tau from microtubules that causes loss of microtubule-stabilizing function (Stoothoff \& Johnson, 2005). Although dynamic tau phosphorylation occurs during embryonic development (Mawal-Dewan et al., 1994), aberrant tau phosphorylation in mature neurons is harmful to the neuron (Matsuo et al., 1994). Tau hyperphosphorylation is a key regulatory mechanism that leads to both such toxic gains-of-function and the loss of the normal function(s) of tau (Ballatore et al., 2007).

Upregulation of aberrant activation of tau kinases and downregulation of phosphatases are major mechanisms possibly involved in tau hyperphosphorylation (Ballatore et al., 2007). Consistently, tau phosphorylation on Ser/Thr-Pro by Pro-directed kinases (Illenberger et al., 1998; Pelech, 1995) or phosphatases such as phosphatase2A (PP2A) (Goedert et al., 2000; Sontag et al., 1996) play pivotal roles in tauopathy. Indeed, overexpression of glycogen synthase kinase-3 $\beta$ (GSK3 $\beta$ ) or cyclin-dependent protein kinases (CDK5) and its activator p25 or inhibition of PP2A enhances or induces tau-related phenotypes in mice (Ahlijanian et al., 2000; Augustinack et al., 2002; Cruz et al., 2003; Kins et al., 2001; Noble et al., 2003). In addition, tau phosphorylation has been shown to promote tau degradation via chaperone-interacting protein/Hsp70 (Dickey et al., 2007; Kosik \& Shimura, 2005; Petrucelli et al., 2004). These results indicate that kinases and phosphatases that increase and decrease phosphorylated tau, respectively, are crucial targets for treatment of $\mathrm{AD}$. Design of inhibitors for these kinases is undertaken as potential drug targets (reviewed in (Mazanetz and Fischer, 2007). 
Regarding amyloid, $A \beta$ varies from 39 to 43 amino acids and arises from sequential $\beta$ - and $\gamma$ secretases processing of the amyloid precursor protein (APP). Presenilin 1 (PS1) is a catalytic subunit of $\gamma$-secretase. Several active and passive immunotherapy approaches such as acceleration of clearance of $A \beta$ from the brain of the AD patients using brain penetrant inhibitors of $A \beta$ aggregation and anti-A $\beta$ monoclonal antibodies are undertaken (Frisardi et al.). Inhibitors of proteases such as $\beta$ - and $\gamma$-secretase regulating A $\beta$ formation from APP and compounds that stimulate $\alpha$-secretase, the enzyme responsible for the non-amyloidogenic metabolism of APP are also investigated (reviewed in Frisardi et al.).

In addition to inhibition of tau phosphorylation and clearance of $A \beta$, an approach that targets protein conformations of tau and APP has been proposed as a new therapeutic target treating AD. Phosphorylation of serine and threonine residues preceding proline (pSer/Thr-Pro) mediated by a large number of so-called Pro-directed protein kinases is a major signaling mechanism (Hunter, 1995; Lu, 2004; Lu et al., 2002). Specific pSer/Thr-Pro motifs in certain proteins such as tau can exist in 2 distinct cis and trans conformations, whose conversion can be greatly accelerated by Pin1 (protein interacting with NIMA 1), a unique prolyl cis-trans isomerase (Lu et al., 1996; Lu et al., 1999b; Yaffe et al., 1997; Zhou et al., 1999). Such Pin1-catalyzed conformational changes, which can now be visualized by nuclear magnetic resonance (NMR) (Pastorino et al., 2006), have a profound impact on phosphorylation signaling, achieved by regulating a spectrum of target activities (Lu, 2004; Lu \& Zhou, 2007; Wulf et al., 2005). Pin1 is tightly regulated and its deregulation contributes to pathological conditions, notably AD and cancer (Butterfield et al., 2006; Lu, 2004; Lu \& Zhou, 2007; Pastorino et al., 2006; Shen et al., 2005; Suizu et al., 2006; Wulf et al., 2005). Remarkably, deletion of Pin1 in mice causes progressive age-dependent tauopathy (Liou et al., 2003). The observation that deprivation of a single molecule causes tauopathy verifies the importance of Pin1 on tauopathy. Conversely, neuronal Pin1 overexpression decreases the stability of tau, and greatly inhibits the tauopathy phenotype in wild-type tau transgenic mice (Lim et al., 2008). In AD, Pin1 binds to and isomerizes the pThr231-Pro motif in tau to restore its ability to bind to microtubules and to promote their assembly (Lu et al., 1999a) by facilitating tau dephosphorylation by PP2A (Liou et al., 2003; Zhou et al., 2000). Moreover, Pin1 binds to the pThr668-Pro motif of APP in the cis and trans conformations, accelerates the isomerization rate (Pastorino et al., 2006) and promotes nonamyloidogenic APP processing, thereby producing neurotrophic $\alpha$ APPs and reducing neurotoxic A $\beta$ peptides (Pastorino et al., 2006).

Because such neurodegeneration-protecting effects by Pin1 are generally believed to be ascribable to cis trans conformational changes by Pin1, regulation of the conformations of tau and APP after phosphorylation likely serves as potential therapeutic target for AD.

In this chapter, we summarize the current understanding of the mechanisms on how Pin1 acts as a protecting molecule against neurodegeneration in AD mouse models, followed by evidences of the pivotal roles of Pin1 in human AD.

\section{Contribution of cis-trans isomerization to neural functions}

The unique stereochemistry of Pro means that it can adopt two completely different conformational states (trans and cis). The significance of this with respect to the fact that Pro is often found next to phosphorylated Ser/Thr residues was not appreciated for a long time (Lu, 2004; Wulf et al., 2005). A breakthrough in understanding the conformational 
importance of Pro-directed phosphorylation motifs was the discovery of a unique and conserved peptidyl-prolyl cis/trans isomerase (PPIase), Pin1 (Lu, 2004; Lu et al., 1996; Ranganathan et al., 1997; Yaffe et al., 1997). Although Pin1 belongs to the parvulin subfamily of PPIases, it is the only PPIase that specifically recognizes pSer/Thr-Pro peptide sequences (Lu, 2004; Lu et al., 1996; Ranganathan et al., 1997; Yaffe et al., 1997), which is especially important because Pro-directed kinases and phosphatases are conformation-specific and act only on the trans conformation (Brown et al., 1999; Weiwad et al., 2000; Zhou et al., 2000). The identification of Pin1 as a phosphorylation-specific PPIase led to a new concept that Pin1 catalytically regulates the conformation of substrates after their phosphorylation to further control protein function (Lu et al., 1999b; Ranganathan et al., 1997; Yaffe et al., 1997; Zhou et al., 1999).

Phosphorylation dramatically slows down the already slow rate of isomerization of Ser/Thr-Pro bonds and renders the phosphopeptide bond resistant to the catalytic action of conventional PPIases (Yaffe et al., 1997). Pro-directed phosphorylation also induces local structural changes that make it accessible to further modifications (Kipping et al., 2001). The striking substrate specificity of Pin1 towards certain pSer/Thr-Pro bonds results from its unique two domain structure consisting of an N-terminal WW domain and a C-terminal PPIase domain, which form a "double-check" mechanism (Ranganathan et al., 1997; Yaffe et al., 1997; Zhou et al., 2000). The WW domain of Pin1 binds only to specific pSer/Thr-Pro motifs, which are often critical regulatory phosphorylation sites in Pin1 substrates (Shen et al. 1998; Lu et al. 1999; Lu et al. 1999; Zhou et al. 2000; Ryo et al. 2001; Wulf et al. 2001; Lu et al. 2002). This WW domain binding targets the Pin1 catalytic domain close to its substrates, where the PPIase domain isomerizes specific pSer/Thr-Pro motifs and catalytically induces conformational changes in proteins (Lu et al., 1999b; Zhou et al., 2000). It remains to be solved why Pin1 binds only to specific pSer/Thr-Pro motifs in certain proteins but it may be due to combined primary (and other) structural determinants. Furthermore, the WW domain can increase or inhibit Pin1 isomerase activity depending on whether a peptide substrate is phosphorylated on a single site or on multiple sites in vitro (Smet et al., 2005), although the biological significance of these findings is unclear. The findings that many substrates contain a single phosphorylation target site for Pin1 suggest that when it is targeted to the substrate by the WW domain, the PPIase domain would have to act on the same pSer/Thr-Pro motif to accelerate its isomerization. Another possibility is that the WW domain and PPIase domain might act on different pSer/Thr-Pro motifs in the same protein or in different ones when a Pin1 substrate is multiphosphorylated or in a multiprotein complex. In contrast to most other constitutively active PPIases (Fischer \& Aumuller, 2003), Pin1 function is tightly regulated at multiple levels under physiological conditions, as expected given the tight regulation of Pro-directed phosphorylation signalling. For example, in neurons, Pin1 expression is induced upon neuronal differentiation (Hamdane et al., 2006; Liou et al., 2003; Lu et al., 1999a). This observation raises the link between prolyl cis-trans isomerization and neural functions.

Indeed, prolyl cis-trans isomerization has been shown to control neural functions. The study that took an initiative in this field is cis and trans specific functions on the opening of a neurotransmitter-gated ion channel in vitro (Lummis et al., 2005). Serotonin (5hydroxytryptamine type 3,5-HT3) receptors are members of the cysteine-loop receptor superfamily (Lester et al., 2004). Neurotransmitter binding in these proteins triggers the opening of an ion channel by inducing cis-trans conformational change (Lummis et al., 2005). 
5-HT3 receptors have a specific proline $\left(\mathrm{P}^{*} 8\right)$ located at the apex of the loop between the second and third transmembrane helices (M2 and M3). When $\mathrm{P}^{*} 8$ is replaced with analogs that favor the trans conformation, closed channels are observed. Conversely, unnatural amino acids that have high cis preference resulted in irreversible open channels. These results suggest that neurotransmitter binding may trigger a conformational change that isomerizes $\mathrm{P}^{*} 8$ from trans to cis (Lummis et al., 2005). Interestingly, proline is often found in the transmembrane regions of ion channels and transporters (Sansom \& Weinstein, 2000), which suggests an important role for the conformational changes in regulating the gating of 5HT3 receptor channel. These results clearly show that prolyl cis-trans isomerization controls physiological neural functions in vitro. A finding that Pin1, a PPIase, enhances the ability of gephyrin to bind the $\beta$-subunit of glycine receptors, which is important for maintaining a high concentration of inhibitory glycine receptors juxtaposed to presynaptic releasing sites (Zita et al., 2007), further suggests an intriguing hypothesis that PPIases might be involved in neural functions, especially pathological neural functions.

Exploration of the contributions of Pin1, a PPIase, to pathological neural functions gave an answer for the hypothesis. Pin1 protects against spinal cord injury by preventing JNK3induced MCL1 degradation, cytochrome $c$ release and apoptosis in vitro and in vivo (Li et al., 2007), which are opposite to the in vitro findings that Pin1 acts on bimEL (also known as Bcell lymphoma protein-2 (bcl2)-like-11) to induce apoptosis (Becker \& Bonni, 2006). Furthermore, evidences for Pin1's protection against neurodegeneration through tau and $\mathrm{APP}$ in vitro and in vivo as shown in the next section confirmed the pivotal role of the PPIase in pathological neural conditions.

\section{Pin1 restores tauopathy phenotype in mice}

\subsection{Pin1 recognizes phosphorylated Thr231 in tau}

Various isoforms of tau appear to be differentially expressed during development, however, the tau isoforms with 3 and 4 tubulin-binding repeats are expressed in a one-to-one ratio in most regions of the adult brain (Ballatore et al., 2007). The primary function of tau is to stabilize microtubules. Tau proteins promote tubulin polymerization and stabilize microtubule structure in vivo (Lindwall \& Cole, 1984; Weingarten et al., 1975). Tau deletion also potentiates the phenotypes of axon tracts and neuronal layers in mice lacking MAP1B, another major MT-associated protein (Takei et al., 2000). In AD brains, neuronal cytoskeleton is progressively disrupted and replaced by NFTs (Alonso et al., 1996). NFTs in $\mathrm{AD}$ are composed of hyperphosphorylated tau in two forms (paired helical filaments (PHF) and straight filaments (SF)). Tau hyperphosphorylation appears to precede tangle formation and neurodegeneration in AD. Hyperphosphorylated tau shows defective microtubule binding, fails to promote microtubule assembly, and self-assembles into NFTs in vitro (Mandelkow, 1999). In contrast, dephosphorylation in vitro can restore the microtubulebinding function and abolish the aggregation of AD phospho-tau (ptau) (Alonso et al., 1996). Taken together, these results indicate that increased tau phosphorylation is a key and an early event in the pathogenesis of human tauopathies, and therefore, dephosphorylation of hyperphosphorylated tau could be an attractive way to restore physiological tau function.

Ser/Thr-Pro sites are major regulatory phosphorylation motif in cells (Blume-Jensen \& Hunter, 2001; Lee \& Tsai, 2003; Lu, 2004; Lu et al., 2003; Nigg, 2001). Enzymes that are responsible for such phosphorylation belong to a large superfamily of Pro-directed protein kinases, which include extracellular signal-regulated kinases (ERKs), stress-activated protein kinases/c-Jun-N- 
terminal kinases (SAPKs/JNKs), p38 kinases and Polo-like kinases (PLKs) in addition to CDKs and GSKs. These kinases have a crucial role in diverse cellular processes such as cell growth regulation, stress responses and neuronal survival, as well as in human diseases such as cancer and AD (Blume-Jensen \& Hunter, 2001; Lee \& Tsai, 2003; Lu, 2004; Lu et al., 2003; Nigg, 2001).

Pin1 binds to tau in a phosphorylation-dependent manner and the binding site was mapped to pThr231 of tau in vitro (Lu et al., 1999a). This phospho-epitope has been proposed to be diagnostic for $\mathrm{AD}$ because its levels in the cerebrospinal fluid correlate with the progression of the disease (Hampel et al., 2001; Kohnken et al., 2000). In addition, the mobility shifted ptau was positively probed by both CP9, an antibody specific for pThr231, and TG3, an antibody detecting Alzheimer-specific conformation of pThr231. In AD brain sections, exogenous Pin1 specifically bound to NFTs and neurites, which were also reactive to Pin1 antibody and TG3, indicating endogenous Pin1 is also localized to the pThr231 site. Biochemically, Pin1 was copurified with PHF. Thus, the Pin1 interaction with ptau has been established.

\subsection{Pin1 restores normal tau function through dephosphorylation of pThr231 of tau in vitro}

Tau phosphorylated by Cdc2 showed a marked decrease in microtubule binding compared to unphosphorylated tau in tau biochemical assay in vitro (Lu et al., 1999a). Pin1-directed restoration of tau's ability to bind to microtubule was revealed by several observations. The loss of ptau's affinity to microtubules could be dramatically rescued by the sole presence of Pin1. The functional consequence of application of Pin1 was derived when microtubule assembly from tubulin was measured based on turbidity changes detected by spectrophotometer. The ability of tau to promote tubulin polymerization was abolished after tau was phosphorylated by Cdc2. Wild-type Pin1, but not the binding of defective point mutant, restored the function.

The involvement of dephosphorylation in the restoration by Pin1 was led by the observations that many of phosphoproteins Pin1 binds to are also recognized by the mitosisand phosphorylation-specific antibody (mAb) MPM-2, and induction of MPM-2 epitopes is a prominent common feature shared by $\mathrm{AD}$, frontotemporal dementia and parkinsonism linked to chromosome 17 (FTDP-17), Down Syndrome, corticobasal degeneration, progressive supranuclear palsy and Pick's disease. Furthermore, various studies have shown that mitotic events, including Cdc2 kinase, are aberrantly activated in the AD brain (Vincent et al., 1997; Vincent et al., 1996) and the phosphorylation pattern of tau in mitotic cells is strikingly similar to that in the AD brain (Kondratick et al. 1996; Vincent et al. 1996; Vincent et al. 1997; Illenberger et al. 1998; Preuss et al. 1998; Vincent et al. 1998). Indeed, both mitotic and $\mathrm{AD}$ tau proteins are recognized by mitosis-specific or AD-specific mAbs that are phosphorylation-dependent. Pin1 binds to pSer/Thr-Pro sites of many MPM-2 antigens, including tau. The phosphorylation dependent cis/trans-isomerization of pSer/Thr-Pro of many MPM-2 antigens is important for cell cycle control (Ding et al., 2000; Lane \& Nigg, 1996; Wells et al., 1999; Winkler et al., 2000). On the other hand, dephosphorylation of the MPM-2 epitopes by phosphatases, notably PP2A, also plays an essential role in the regulation of Cdc2 activation and mitosis (Evans \& Stark, 1997; Kawabe et al., 1997; Kinoshita et al., 1990; Lee, 1995; Lin \& Arndt, 1995; Sontag et al., 1995). Interestingly, using metabolically active rat brain slices as a model, Gong et al. (Gong et al., 2000) showed that down-regulation of PP2A by okadaic acid induced Alzheimer-like hyperphosphorylation of tau. In contrast, the inhibition of PP2B by cyclosporin A in the same system did not significantly affect tau phosphorylation. 
The pure cis isomer of tau peptide can be obtained using trans-specific $\alpha$-chymotrypsin to eliminate the trans isomer (Zhou et al., 2000). In the absence of any PPIases, it took about 2.5 $\mathrm{h}$ to convert the pure cis peptide to equilibrium state, which is about $15 \%$ cis. Importantly, the pure cis peptides cannot be dephosphorylated by PP2A (Zhou et al., 2000). The pThr-Pro peptides were dephosphorylated by PP2A with a rate almost identical to that of trans isomer appearance. The trans isomer-dependent dephosphorylation was neither observed with alkaline phosphatase nor with a non-Pro-containing peptide. These experiments indicated that PP2A is a trans conformation-specific phosphatase. Indeed, the presence of Pin1 accelerated the dephosphorylation of tau by PP2A. However, the effect of Pin1 on PP2A dephosphorylation was not observed in tau Thr231Ala mutant. Taken together, Pin1 facilitates the dephosphorylation of pThr231-Pro site in tau through PP2A likely leads to the restoration of tau-mediated microtubule function.

\subsection{Pin1 degrades hyperphosphorylated tau}

Another effective way to treat tauopathy might be the elimination of hyperphosphorylated tau. It has been shown that tau phosphorylation regulates its degradation (Dickey et al., 2007; Kosik \& Shimura, 2005; Petrucelli et al., 2004; Poppek et al., 2006) and that protein degradation is modulated by Pin1 (Lu \& Zhou, 2007). These results suggest that Pin1 might act on the pThr231-Pro motif in tau to regulate the protein stability. Pin1 knockdown caused tau to become highly stable in neuron-like SH-SY5Y cells under cycloheximide experiment (Lim et al., 2008). Importantly, the effect of Pin1 knockdown on tau protein stability was completely abolished in the presence of the proteosome inhibitor MG132, demonstrating that the effect of Pin1 knockdown depends on functional proteosome, as shown for other Pin1 substrates (Lu \& Zhou, 2007). The result was replicated in neurons isolated from mice. Transfected tau protein in primary cultured neurons and tau protein in brain slices from tau transgenic mouse were significantly more stable in Pin1-knockout background (Lu \& Zhou, 2007). Further examination was carried out under Pin1 transgenic background in mice in which Pin1 transgene is expressed under Thy1.2 promoter that is active in neurons approximately 10 days after birth (Caroni, 1997). In the double transgenic mice having both tau transgene and Pin1 transgene, tau phosphorylation on Thr231 was reduced compared to tau transgene alone.

Tau phosphorylation has been shown to promote tau degradation via chaperoneinteracting protein/Hsp70 (Dickey et al., 2007; Kosik \& Shimura, 2005; Petrucelli et al., 2004) or inhibit tau degradation (Poppek et al., 2006). Interestingly, F-box proteins, which target phosphorylated proteins to ubiquitin-mediated proteolysis, bind to pSer/Thr-Pro motifs only in trans, but not cis (Orlicky et al., 2003). One model is that proteins targeting phosphorylated tau for degradation might bind to certain pSer/ThrPro motif(s) in tau only in trans conformation that would promote this interaction to promote degradation of tau. In this model, although tau is probably phosphorylated on certain Ser/Thr-Pro motifs such as the Thr231-Pro motif in trans due to the conformation specificity of kinases (Lu \& Zhou, 2007), the pThr231-Pro motif in tau might have a tendency to be in the cis conformation due to local structural constraints after phosphorylation, as shown for APP (Ramelot \& Nicholson, 2001). Therefore, in the nonequilibrium cellular environment, Pin1 overexpression might greatly accelerate the cis to trans isomerization to promote tau degradation, whereas Pin1 inhibition might allow a higher concentration of cis pThr231-Pro motif to be present for a longer time, which might inhibit tau degradation (Figure 1). 


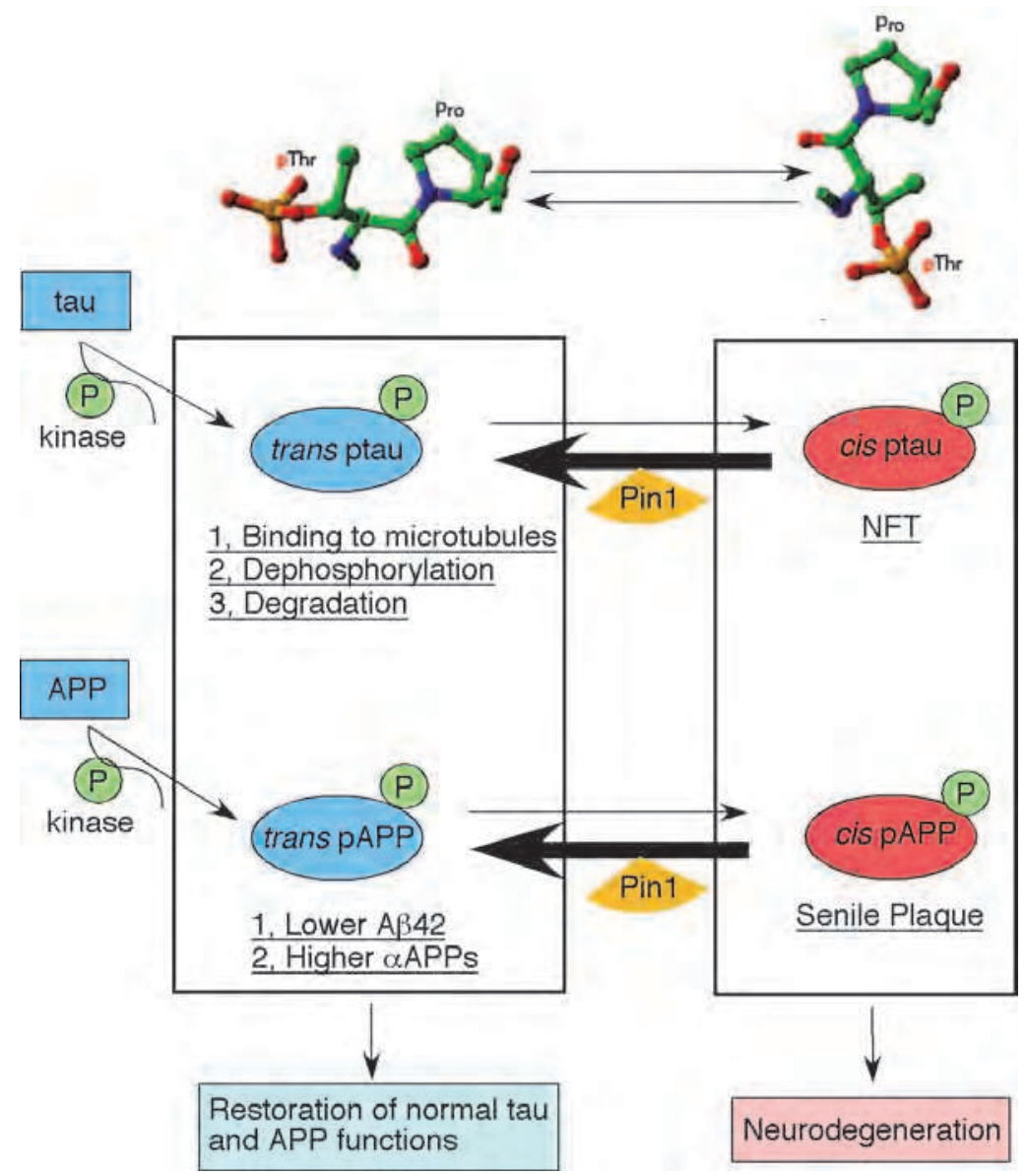

Tau and APP may be phosphorylated by protein kinases as part of their normal functions. Cis-ptau is resistant to binding to microtubules, protein phosphatases and degradation. By catalysing isomerization of the cis to trans conformation, Pin1 facilitates binding to microtubules and restores normal tau function. Pin1 also promotes tau dephosphorylation by phosphatases that contributes to the binding to microtubules. The cis to trans transition by Pin1 also facilitates degradation of phosphorylated tau. Regarding APP, cis-pAPP represents amyloidogenic APP processing. Pin1 catalyses isomerization of the cis to trans conformation, thereby, inducing decreased $A \beta 42$ and increased $\alpha$ APPs. The trans-conformations of ptau and pAPP may represent the physiological conformations that promote their normal functions.

Fig. 1. Restoration of tau and APP functions by Pin1.

Importantly, in 18-month-old tau transgenic mice, neuropathological changes, as demonstrated by the presence of some silver-positive neurons in the ventral horn of spinal cord and several degenerating or demyelinated axons within the sciatic nerves were found. However, neither silver-positive neurons in the spinal cord nor degenerated neurons within the sciatic nerve was observed in double transgenic mice having both Pin1 transgene and wild-type tau transgene (Lim et al., 2008). This result indicates that Pin1 overexpression effectively inhibits spinal and peripheral neuropathies induced by tau overexpression. 


\subsection{Deletion of Pin1 causes tauopathy in mice}

Pin1 knockout mice (Liou et al., 2003) serves as a good tool to investigate the effect of Pin1 on endogenous tau in vivo. Pin1-deficient mice showed progressive age-dependent motor and behavioral deficits including abnormal limb-clasping reflexes, hunched postures and reduced mobility (Liou et al., 2003) similar to tau transgenic mice (Allen et al., 2002; Lewis et al., 2000). These phenotypes in Pin1 mutant mice are significant because the total level of NFTs correlates with the degree of cognitive impairment (Arriagada et al., 1992a; Arriagada et al., 1992b). Pioneering studies that used immunohistochemical techniques to determine the level of both NFTs and senile plaques in different brain regions of AD patients, as well as non-demented elderly individuals, demonstrated that the number of NFTs, but not the numbers of senile plaques, correlates with the degree of cognitive impairment (Arriagada et al., 1992a; Arriagada et al., 1992b).

Since neuron number in the parietal cortex of old, but not young mutant mice were significantly decreased, these phenotypes were caused by neuronal loss. A similar neuronal degeneration was found in spinal cords of the knockout mice (Liou et al., 2003). Tau hyperphosphorylation has been observed in aged mutant mice, with a dramatic mobility shift that is reversed by phosphatase treatment (Liou et al., 2003). The retarded forms of ptau in the mutant mice were also detected by various phospho-specific or Alzheimerconformation-specific antibodies, such as AT180 and TG3. The phosphatase activity specific to pThr231 peptide motif was significantly reduced in the mutant mice, which is in agreement with Pin1's role in facilitating PP2A phosphatase activity. In aged Pin1-deficient mice, immunohistochemical staining of the hippocampus, cortex and spinal cord with specific ptau antibodies showed distinct somatodendritic signals, indicating pathological localization of tau. In Pin1-deficient mice, immunoelectronmicroscopic analysis showed that NFT-like tau filaments decorated by AT180 gold label were isolated from sarkosyl insoluble fractions (Liou et al., 2003). The tau filaments isolated resembled some of the human FTDP17 mutants (Allen et al., 2002; Gotz et al., 2001; Lewis et al., 2000; Lim et al., 2001; Tanemura et al., 2002). Gallyas and thioflavin-staining, two established methods detecting NFTs in AD brains, were immense in entorhinal cortex and hippocampus, brain regions where impaired neuronal function appears initially in AD (Liou et al., 2003). These phenotypes are noteworthy because no gene deletion model has been reported to spontaneously cause tau pathology, thus no endogenous protective mechanism has been proposed.

\section{Pin1 reduces $A b$ in mice}

Tau and APP are two major molecules for AD. A growing body of evidence indicates some common features between the normal cell cycle and degenerated AD neurons, especially mitotic phosphorylation on certain Ser/Thr-Pro motifs (Lu et al., 2003; Yang \& Herrup, 2007). Phosphorylation of APP on the Thr668-Pro motif, which occurs in mitotic cells (Suzuki et al., 1994), is also increased in AD brains and can elevate A $\beta$ secretion in vitro (Lee et al., 2003).

Nuclear magnetic resonance (NMR) analysis of the action of Pin1 on APP has revealed the dynamic regulation of the intracellular domain of APP between the two completely distinct structures (Pastorino et al., 2006). APP possesses a Thr668-Pro motif that exists in trans before phosphorylation. The cis conformation appears only after phosphorylation due to local structural constraints, with $\sim 10 \%$ of the phosphorylated motifs existing in the cis conformation (Ramelot \& Nicholson, 2001). Pin1 binds to the pThr668-Pro motif in the cis and trans conformations and also accelerates the isomerization rate $>1000$-fold (in the 
millisecond timescale) compared with the typical uncatalysed reaction (which is in the minute timescale), with the catalysed cis to trans rate being 10-fold faster than the reverse rate (Pastorino et al., 2006), in contrast to a recent report that Pin1 does not act on full-length protein (Akiyama et al., 2005). Therefore, Pin1 would rapidly re-establish cis/trans equilibrium if either population was suddenly depleted in the cell.

APP processing is determined by APP subcellular localization and occurs through nonamyloidogenic processing at the plasma membrane by $\alpha$-secretases or amyloidogenic processing at endosomes by $\beta$-secretase (De Strooper \& Annaert, 2000; Esler \& Wolfe, 2001; Hardy \& Selkoe, 2002; Mattson, 2004; Selkoe et al., 1996). There is observation Pin1 colocalizes with APP at plasma membrane but not at endosomes, suggesting Pin1 affects APP intracellular localization and therefore affect APP processing and $\mathrm{A} \beta$ production (Pastorino et al., 2006). In addition, in Pin1 knockout mice, a significant increase in A $\beta 42$ level in brain is observed (Pastorino et al., 2006).

Importantly, functional consequence of Pin1 deregulation revealed that the cis pThr668-Pro motif has a longer lifetime and its population relative to trans can be shifted far from its equilibrium depending on isomer-specific interactions, which might favor more amyloidogenic APP processing and A $\beta$ production without proper Pin1 function (Figure 1). Therefore, in collaboration with other Alzheimer's disease factors, Pin1 deregulation might promote amyloidogenic APP processing and A $\beta$ production and thus contribute to the pathology of AD (Pastorino et al., 2006).

\section{Involvement of Pin1 in human AD}

Positional cloning led to the identification of rare, disease-causing mutations in APP, PSEN1, and PSEN2 causing early-onset familial AD, followed by the discovery of ApoE as the only widely accepted and replicated risk factor for late-onset AD. In addition, recent genome-wide association approaches have delivered several additional AD susceptibility loci that are common in the general population (reviewed in Bertram \& Tanzi, 2009).

Pin1 is mapped to 19p13.2, which has been identified as a novel locus for late onset AD that is independent of the effect of ApoE4 (Butler et al., 2009; Wijsman et al., 2004). Several common polymorphisms have been identified in the coding and promoter regions of Pin1. The relationship between Pin1 level and AD is of particular interest because Pin1 is downregulated and/or inhibited by oxidative modifications in AD (Liou et al., 2003; Sultana et al., 2006). Previous studies showed that Pin1 promoter single nucleotide polymorphism (SNP) $(842 \mathrm{G}>\mathrm{C})$ is associated with reduced level of Pin1 in blood cells and increased risk for AD in an Italian cohort (Segat et al., 2007), although not in other cohorts (Lambert et al., 2009; Nowotny et al., 2007). Further studies have confirmed that this SNP abolishes Pin1 promoter activity and is associated with reduced risk for multiple cancers(Han et al., 2010). It is possible that the undetected population structure in studies with heterogeneous populations of subjects can lead to false positive results or failures in detecting the association with disease (Marchini et al., 2004) and this effect increased with samples size which might explain the conflicting results among the studies on Pin1 promoter polymorphisms. It has been shown that Chinese and Japanese subpopulations are more homogeneous and have a lower degree of population admixture (Marchini et al., 2004). Using Chinese subjects, we recently studied the onset of AD and Pin1 polymorphism. A functional polymorphism in the Pin1 promoter (rs2287839) was identified and this polymorphism was significantly associated with a 3-year delay in the onset of AD (Ma et 
al.). The base change of the SNP abolished the binding site of AP4 and increased the expression level of Pin1 in AD (Ma et al.). AP4 belongs to the basic helix-loop-helix leucinezipper (bHLH-LZ) subgroup of bHLH proteins and recognizes the symmetrical DNA core sequence CAGCTG (Hu et al., 1990). Our result on AP4 RNAi and AP4 overexpression in H4 cells showed AP4 was able to repress the expression of Pin1 through the AP4 binding site in the promoter region of Pin1.

The above result is confirmed by biochemical and histochemical approaches using AD brain. Pin1 translocation from the soluble fractions to the insoluble fractions was reported in AD brains, while it was mainly present in the soluble fraction in age matched normal brain samples (Lu et al., 1999a). Further histological studies clarified Pin1's impact on $\mathrm{AD}$. In the hippocampus and neocortex, the neurons in specific subregions are more prone to neurofibrillary degeneration than the neighboring subregions, indicating stereotypical patterns of neurodegeneration in AD. In the hippocampus, expression of Pin1 was relatively higher in CA4, CA3, CA2 and presubiculum, and lower in CA1 and subiculum. In the parietal cortex, expression of Pin1 was relatively higher in layer IIIb-c neurons, and lower in layer $\mathrm{V}$ neurons. The subregions with low expression of Pin1 coincide with the subregions that are more susceptible to neurofibrillary degeneration in $\mathrm{AD}$, whereas those containing high Pin1 expression are not, showing an inverse correlation between Pin1 expression and predicted vulnerability (Liou et al., 2003). In AD brains, tangle-bearing neurons were enriched in CA1 and subiculum of the hippocampus and in layer V of the parietal cortex (Arriagada et al., 1992b; Davies et al., 1992; Hof \& Morrison, 1991; Pearson et al., 1985). Overall, Pin1 level is generally low in these regions (Liou et al., 2003).

Because Pin1 is important in modulating APP processing in mice and has an inverse relationship with tau accumulation in human AD, increased Pin1 expression resulting from the base substitution of the SNP might delay the pathological process of AD, thus delaying the age of onset of AD (Figure 2). This result is significant because an intervention that could delay the average age of onset of $\mathrm{AD}$ by only 2 years has been predicted to reduce the expected prevalence by $23 \%$ by 2050 (Brookmeyer et al., 1998).
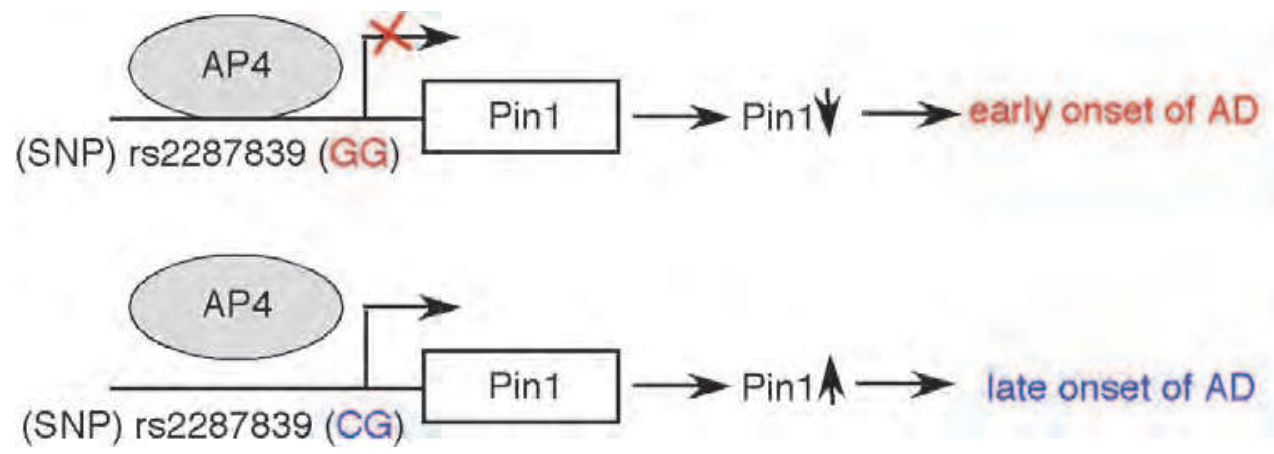

A transcription factor AP4 binds to wild type GG genotype in the Pin1 promoter (rs2287839) and represses its transcription. The polymorphism (CG) abolishes the binding site of AP4 and disinhibits the repression, thereby increases Pin1 expression level in AD. The polymorphism results in 3-year delay of the onset of AD.

Fig. 2. A Pin1 polymorphism associates with delayed onset of AD. 


\section{Conclusions}

Tau and APP, two major causative molecules for $\mathrm{AD}$, are reasonable and attractive therapeutic targets. The links between tau malfunctions and an overall imbalance in the activity levels or regulation of tau kinases and phosphatases have been established (Churcher, 2006; Mazanetz \& Fischer, 2007). Although, attempts to identify AD-specific phosphorylation sites on tau have yet to yield conclusive results (Gordon-Krajcer et al., 2000; Schneider et al., 1999), the most probable candidates are Ser262 and the region around Thr231 and Ser235 (Hasegawa et al., 1992; Kohnken et al., 2000). Among these sites, Ser262 is identified as a Lys-Xaa-Gly-Ser motif recognized by Par1 kinase (microtubule associated regulating kinase) (Doerflinger et al., 2003; Drewes et al., 1995; Nishimura et al., 2004), whereas pSer/Thr-Pro sites of Thr231 and Ser235 are phosphorylated by CDKs, MAPKs, and/or GSKs (Ishiguro et al. 1993; Sperber et al. 1995; Zheng-Fischhofer et al. 1998; Ahlijanian et al. 2000; Reynolds et al. 2000; Takashima et al. 2001). These pro-directed kinases also target other pSer/Thr-Pro sites of tau. A hierarchy of phosphorylation regulation by different kinases has been implicated in the cascade of hyperphosphorylation and certain sites may play an initiative role (Jicha et al., 1999; Zheng-Fischhofer et al., 1998). GSK3 $\beta$ or CDK5 has been suggested to induce pre-tangle or NFT phenotypes, respectively (Lucas et al., 2001; Noble et al., 2003; Phiel et al., 2003). Thus, these tau kinases have received particular attention as targets for disease-modifying therapies using inhibitory compounds. Clearance of $A \beta$ is also a logical therapeutic approach. If these inhibitor drugs can reach the brain efficiently from systemic circulation by crossing the blood-brain barrier, those might be attractive therapeutic approaches.

The discovery of the phosphorylation-specific PPIase Pin1 has established conformational regulation after phosphorylation as a new signaling mechanism. Pin1 could restore both tau and APP processing through their conformational changes. Thus, Pin1 might provide the opportunity for exploring more efficient therapy for AD than that targeting either tau or APP. A major challenge for the future will be to stably express Pin1 in the AD brain to normalize tau and APP processing.

\section{References}

Ahlijanian, M.K., Barrezueta, N.X., Williams, R.D., Jakowski, A., Kowsz, K.P., McCarthy, S., Coskran, T., Carlo, A., Seymour, P.A., Burkhardt, J.E., Nelson, R.B. \& McNeish, J.D. (2000). Hyperphosphorylated tau and neurofilament and cytoskeletal disruptions in mice overexpressing human $\mathrm{p} 25$, an activator of cdk5. Proceedings of the National Academy of Sciences USA, Vol. 97, No. 6, pp. 2910-2915, ISSN 0027-8424

Akiyama, H., Shin, R.W., Uchida, C., Kitamoto, T. \& Uchida, T. (2005). Pin1 promotes production of Alzheimer's amyloid beta from beta-cleaved amyloid precursor protein. Biochemical and Biophysical Research Communications, Vol. 336, No. 2, pp. 521-529, ISSN 0006-291X

Allen, B., Ingram, E., Takao, M., Smith, M.J., Jakes, R., Virdee, K., Yoshida, H., Holzer, M., Craxton, M., Emson, P.C., Atzori, C., Migheli, A., Crowther, R.A., Ghetti, B., Spillantini, M.G. \& Goedert, M. (2002). Abundant tau filaments and nonapoptotic neurodegeneration in transgenic mice expressing human P301S tau protein. Journal of Neuroscience, Vol. 22, No. 21, pp. 9340-9351, ISSN 0270-6474 
Alonso, A.C., Grundke-Iqbal, I. \& Iqbal, K. (1996). Alzheimer's disease hyperphosphorylated tau sequesters normal tau into tangles of filaments and disassembles microtubules. Nature Medicine, Vol. 2, No. 7, pp. 783-787, ISSN 1078-8956

Arriagada, P.V., Growdon, J.H., Hedley-Whyte, E.T. \& Hyman, B.T. (1992a). Neurofibrillary tangles but not senile plaques parallel duration and severity of Alzheimer's disease. Neurology, Vol. 42, No. 3 Pt 1, pp. 631-639, ISSN 0028-3878

Arriagada, P.V., Marzloff, K. \& Hyman, B.T. (1992b). Distribution of Alzheimer-type pathologic changes in nondemented elderly individuals matches the pattern in Alzheimer's disease. Neurology, Vol. 42, No. 9, pp. 1681-1688, ISSN 0028-3878

Augustinack, J.C., Schneider, A., Mandelkow, E.M. \& Hyman, B.T. (2002). Specific tau phosphorylation sites correlate with severity of neuronal cytopathology in Alzheimer's disease. Acta Neuropathologica, Vol. 103, No. 1, pp. 26-35, ISSN 00016322

Ballatore, C., Lee, V.M. \& Trojanowski, J.Q. (2007). Tau-mediated neurodegeneration in Alzheimer's disease and related disorders. Nature Reviews Neuroscience, Vol. 8, No. 9, pp. 663-672, ISSN 1471-0048

Becker, E.B. \& Bonni, A. (2006). Pin1 mediates neural-specific activation of the mitochondrial apoptotic machinery. Neuron, Vol. 49, No. 5, pp. 655-662, ISSN 0896-6273

Bertram, L. \& Tanzi, R.E. (2009). Genome-wide association studies in Alzheimer's disease. Human Molecular Genetics, Vol. 18 (R2), pp. R137-145, ISSN 0964-6906

Blume-Jensen, P. \& Hunter, T. (2001). Oncogenic kinase signalling. Nature, Vol. 411, No. 6835, pp. 355-365, ISSN 0028-0836

Brookmeyer, R., Gray, S. \& Kawas, C. (1998). Projections of Alzheimer's disease in the United States and the public health impact of delaying disease onset. American Journal of Public Health, Vol. 88, No. 9, pp. 1337-1342, ISSN 0090-0036

Brown, N.R., Noble, M.E., Endicott, J.A. \& Johnson, L.N. (1999). The structural basis for specificity of substrate and recruitment peptides for cyclin-dependent kinases. Nature Cell Biology, Vol. 1, No.7, pp. 438-443, ISSN 1097-6256

Butler, A.W., Ng, M.Y., Hamshere, M.L., Forabosco, P., Wroe, R., Al-Chalabi, A., Lewis, C.M. \& Powell, J.F. (2009). Meta-analysis of linkage studies for Alzheimer's disease-a web resource. Neurobiology of Aging, Vol. 30, No. 7, pp. 1037-1047, ISSN 0197-4580

Butterfield, D.A., Abdul, H.M., Opii, W., Newman, S.F., Joshi, G., Ansari, M.A. \& Sultana, R. (2006). Pin1 in Alzheimer's disease. Journal of Neurochemistry, Vol. 98, No. 6, pp. 1697-1706, ISSN 0022-3042

Caroni, P. (1997). Overexpression of growth-associated proteins in the neurons of adult transgenic mice. Journal of Neuroscience Methods, Vol. 71, No. 1, pp. 3-9, ISSN 01650270

Churcher, I. (2006). Tau therapeutic strategies for the treatment of Alzheimer's disease. Current Topics in Medicinal Chemistry, Vol. 6, No. 6, pp. 579-595, ISSN 1568-0266

Cruz, J.C., Tseng, H.C., Goldman, J.A., Shih, H. \& Tsai, L.H. (2003). Aberrant Cdk5 activation by p25 triggers pathological events leading to neurodegeneration and neurofibrillary tangles. Neuron, Vol. 40, No. 3, pp. 471-483, ISSN 0896-6273

Davies, D.C., Horwood, N., Isaacs, S.L. \& Mann, D.M. (1992). The effect of age and Alzheimer's disease on pyramidal neuron density in the individual fields of the hippocampal formation. Acta Neuropathologica, Vol. 83, No. 5, pp. 510-517, ISSN 0001-6322 
De Strooper, B. \& Annaert, W. (2000). Proteolytic processing and cell biological functions of the amyloid precursor protein. Journal of Cell Science, Vol. 113 (Pt 11), pp. 1857-1870, ISSN 0021-9533

Dickey, C.A., Kamal, A., Lundgren, K., Klosak, N., Bailey, R.M., Dunmore, J., Ash, P., Shoraka, S., Zlatkovic, J., Eckman, C.B., Patterson, C., Dickson, D.W., Nahman, N.S., Jr., Hutton, M., Burrows, F. \& Petrucelli, L. (2007). The high-affinity HSP90CHIP complex recognizes and selectively degrades phosphorylated tau client proteins. Journal of Clinical Investigation, Vol. 117, No. 3, pp. 648-658, ISSN 0021-9738

Ding, X.L., Husseman, J., Tomashevski, A., Nochlin, D., Jin, L.W. \& Vincent, I. (2000). The cell cycle Cdc25A tyrosine phosphatase is activated in degenerating postmitotic neurons in Alzheimer's disease. American Journal of Pathology, Vol. 157, No. 6, pp. 1983-1990, ISSN 1525-2191

Doerflinger, H., Benton, R., Shulman, J.M. \& St Johnston, D. (2003). The role of PAR-1 in regulating the polarised microtubule cytoskeleton in the Drosophila follicular epithelium. Development, Vol. 130, No. 17, pp. 3965-3975, ISSN 0950-1991

Drewes, G., Trinczek, B., Illenberger, S., Biernat, J., Schmitt-Ulms, G., Meyer, H.E., Mandelkow, E.M. \& Mandelkow, E. (1995). Microtubule-associated protein/microtubule affinity-regulating kinase (p110mark). A novel protein kinase that regulates tau-microtubule interactions and dynamic instability by phosphorylation at the Alzheimer-specific site serine 262. Journal of Biological Chemistry, Vol. 270, No. 13, pp 7679-7688, ISSN 0021-9258

Esler, W.P. \& Wolfe, M.S. (2001). A portrait of Alzheimer secretases--new features and familiar faces. Science, Vol. 293, No. 5534, pp 1449-1454, ISSN 0036-8075

Evans, D.A., Funkenstein, H.H., Albert, M.S., Scherr, P.A., Cook, N.R., Chown, M.J., Hebert, L.E., Hennekens, C.H. \& Taylor, J.O. (1989). Prevalence of Alzheimer's disease in a community population of older persons. Higher than previously reported. JAMA, Vol. 262, No. 18, pp. 2551-2556, ISSN 0002-9955

Evans, D.R. \& Stark, M.J. (1997). Mutations in the Saccharomyces cerevisiae type 2A protein phosphatase catalytic subunit reveal roles in cell wall integrity, actin cytoskeleton organization and mitosis. Genetics, Vol. 145, No. 2, pp. 227-241, ISSN 0016-6731

Fischer, G. \& Aumuller, T. (2003). Regulation of peptide bond cis/trans isomerization by enzyme catalysis and its implication in physiological processes. Reviews of Physiology, Biochemistry \& Pharmacology, Vol. 148, pp. 105-150, ISSN 0303-4240

Frisardi, V., Solfrizzi, V., Imbimbo, P.B., Capurso, C., D'Introno, A., Colacicco, A.M., Vendemiale, G., Seripa, D., Pilotto, A., Capurso, A. \& Panza, F. (2010). Towards disease-modifying treatment of Alzheimer's disease: drugs targeting beta-amyloid. Current Alzheimer Research, Vol. 7, No. 1, pp. 40-55, ISSN 1567-2050

Goedert, M., Satumtira, S., Jakes, R., Smith, M.J., Kamibayashi, C., White, C.L., 3rd \& Sontag, E. (2000). Reduced binding of protein phosphatase 2A to tau protein with frontotemporal dementia and parkinsonism linked to chromosome 17 mutations. Journal of Neurochemistry, Vol. 75, No. 5, pp. 2155-2162, ISSN 0022-3042

Gong, C.X., Lidsky, T., Wegiel, J., Zuck, L., Grundke-Iqbal, I. \& Iqbal, K. (2000). Phosphorylation of microtubule-associated protein tau is regulated by protein phosphatase 2A in mammalian brain. Implications for neurofibrillary degeneration in Alzheimer's disease. Journal of Biological Chemistry, Vol. 275, No. 8, pp. 5535-5544, ISSN 0021-9258

Gordon-Krajcer, W., Yang, L. \& Ksiezak-Reding, H. (2000). Conformation of paired helical filaments blocks dephosphorylation of epitopes shared with fetal tau except 
Ser199/202 and Ser202/Thr205. Brain Research, Vol. 856, No. 1-2, pp. 163-175, ISSN 0006-8993

Gotz, J., Chen, F., Barmettler, R. \& Nitsch, R.M. (2001). Tau filament formation in transgenic mice expressing P301L tau. Journal of Biological Chemistry, Vol. 276, No. 1, pp. 529534, ISSN 0021-9258

Hamdane, M., Dourlen, P., Bretteville, A., Sambo, A.V., Ferreira, S., Ando, K., Kerdraon, O., Begard, S., Geay, L., Lippens, G., Sergeant, N., Delacourte, A., Maurage, C.A., Galas, M.C. \& Buee, L. (2006). Pin1 allows for differential Tau dephosphorylation in neuronal cells. Molecular and Cellular Neurosciences, Vol. 32, No. 1-2, pp. 155-160, ISSN 1044-7431

Hampel, H., Buerger, K., Kohnken, R., Teipel, S.J., Zinkowski, R., Moeller, H.J., Rapoport, S.I. \& Davies, P. (2001). Tracking of Alzheimer's disease progression with cerebrospinal fluid tau protein phosphorylated at threonine 231. Annals of Neurology, Vol. 49, No. 4, pp. 545-546, ISSN 0364-5134

Han, C.H., Lu, J., Wei, Q., Bondy, M.L., Brewster, A.M., Yu, T.K., Buchholz, T.A., Arun, B.K. \& Wang, L.E. (2010). The functional promoter polymorphism $(-842 \mathrm{G}>\mathrm{C})$ in the PIN1 gene is associated with decreased risk of breast cancer in non-Hispanic white women 55 years and younger. Breast cancer research and treatment, Vol. 122, No. 1, pp. 243-249, ISSN 0167-6806

Hardy, J. \& Selkoe, D.J. (2002). The amyloid hypothesis of Alzheimer's disease: progress and problems on the road to therapeutics. Science, Vol. 297, No. 5580, pp. 353-356, ISSN 0036-8075

Hasegawa, M., Morishima-Kawashima, M., Takio, K., Suzuki, M., Titani, K. \& Ihara, Y. (1992). Protein sequence and mass spectrometric analyses of tau in the Alzheimer's disease brain. Journal of Biological Chemistry, Vol. 267, No. 24, pp. 17047-17054, ISSN 0021-9258

Hof, P.R. \& Morrison, J.H. (1991). Neocortical neuronal subpopulations labeled by a monoclonal antibody to calbindin exhibit differential vulnerability in Alzheimer's disease. Experimantal Neurology, Vol. 111, No. 3, pp. 293-301, ISSN 0014-4886

$\mathrm{Hu}$, Y.F., Luscher, B., Admon, A., Mermod, N. \& Tjian, R. (1990). Transcription factor AP-4 contains multiple dimerization domains that regulate dimer specificity. Genes $\mathcal{E}$ Development, Vol. 4, No. 10, pp. 1741-1752, ISSN 0890-9369

Hunter, T. (1995). Protein kinases and phosphatases: the yin and yang of protein phosphorylation and signaling. Cell, Vol. 80, No. 2, pp. 225-236, ISSN 0092-8674

Illenberger, S., Zheng-Fischhofer, Q., Preuss, U., Stamer, K., Baumann, K., Trinczek, B., Biernat, J., Godemann, R., Mandelkow, E.M. \& Mandelkow, E. (1998). The endogenous and cell cycle-dependent phosphorylation of tau protein in living cells: implications for Alzheimer's disease. Molecular Biology of the Cell, Vol. 9, No. 6, pp. 1495-1512, ISSN 1059-1524

Jicha, G.A., O'Donnell, A., Weaver, C., Angeletti, R. \& Davies, P. (1999). Hierarchical phosphorylation of recombinant tau by the paired-helical filament-associated protein kinase is dependent on cyclic AMP-dependent protein kinase. Journal of Neurochemistry, Vol. 72, No. 1, pp. 214-224, ISSN 0022-3042

Kawabe, T., Muslin, A.J. \& Korsmeyer, S.J. (1997). HOX11 interacts with protein phosphatases PP2A and PP1 and disrupts a G2/M cell-cycle checkpoint. Nature, Vol. 385, No. 6615, pp. 454-458, ISSN 0028-0836 
Kinoshita, N., Ohkura, H. \& Yanagida, M. (1990). Distinct, essential roles of type 1 and 2A protein phosphatases in the control of the fission yeast cell division cycle. Cell, Vol. 63, No. 2, pp. 405-415, ISSN 0092-8674

Kins, S., Crameri, A., Evans, D.R., Hemmings, B.A., Nitsch, R.M. \& Gotz, J. (2001). Reduced protein phosphatase 2A activity induces hyperphosphorylation and altered compartmentalization of tau in transgenic mice. Journal of Biological Chemistry, Vol. 276, No. 41, pp. 38193-38200, ISSN 0021-9258

Kipping, M., Zarnt, T., Kiessig, S., Reimer, U., Fischer, G. \& Bayer, P. (2001). Increased backbone flexibility in threonine45-phosphorylated hirudin upon $\mathrm{pH}$ change. Biochemistry, Vol. 40, No. 27, pp. 7957-7963, ISSN 0006-2960

Kohnken, R., Buerger, K., Zinkowski, R., Miller, C., Kerkman, D., DeBernardis, J., Shen, J., Moller, H.J., Davies, P. \& Hampel, H. (2000). Detection of tau phosphorylated at threonine 231 in cerebrospinal fluid of Alzheimer's disease patients. Neuroscience Letters, Vol. 287, No. 3, pp. 187-190, ISSN 0304-3940

Kosik, K.S. \& Shimura, H. (2005). Phosphorylated tau and the neurodegenerative foldopathies. Biochimica et Biophysica Acta, Vol. 1739, No. 2-3, pp. 298-310, ISSN 0006-3002

Lambert, J.C., Heath, S., Even, G., Campion, D., Sleegers, K., Hiltunen, M., Combarros, O., Zelenika, D., Bullido, M.J., Tavernier, B., Letenneur, L., Bettens, K., Berr, C., Pasquier, F., Fievet, N., Barberger-Gateau, P., Engelborghs, S., De Deyn, P., Mateo, I., Franck, A., Helisalmi, S., Porcellini, E., Hanon, O., de Pancorbo, M.M., Lendon, C., Dufouil, C., Jaillard, C., Leveillard, T., Alvarez, V., Bosco, P., Mancuso, M., Panza, F., Nacmias, B., Bossu, P., Piccardi, P., Annoni, G., Seripa, D., Galimberti, D., Hannequin, D., Licastro, F., Soininen, H., Ritchie, K., Blanche, H., Dartigues, J.F., Tzourio, C., Gut, I., Van Broeckhoven, C., Alperovitch, A., Lathrop, M. \& Amouyel, P. (2009). Genome-wide association study identifies variants at CLU and CR1 associated with Alzheimer's disease. Nature Genetics, Vol. 41, No. 10, pp. 1094-1099, ISSN 1061-4036

Lane, H.A. \& Nigg, E.A. (1996). Antibody microinjection reveals an essential role for human polo-like kinase 1 (Plk1) in the functional maturation of mitotic centrosomes. Journal of Cell Biology, Vol. 135, No. 6 Pt 2, pp. 1701-1713, ISSN 0021-9525

Lee, M.S., Kao, S.C., Lemere, C.A., Xia, W., Tseng, H.C., Zhou, Y., Neve, R., Ahlijanian, M.K. \& Tsai, L.H. (2003). APP processing is regulated by cytoplasmic phosphorylation. Journal of Cell Biology, Vol. 163, No. 1, pp. 83-95, ISSN 0021-9525

Lee, M.S. \& Tsai, L.H. (2003). Cdk5: one of the links between senile plaques and neurofibrillary tangles? Journal of Alzheimer's Disease, Vol. 5, No. 2, pp. 127-137, ISSN 1387-2877

Lee, T.H. (1995). The role of protein phosphatase type-2A in the Xenopus cell cycle: initiation of the G2/M transition. Seminars in Cancer Biology, Vol. 6, No. 4, pp. 203209, ISSN 1044-579X

Lester, H.A., Dibas, M.I., Dahan, D.S., Leite, J.F. \& Dougherty, D.A. (2004). Cys-loop receptors: new twists and turns. Trends in Neurosciences, Vol. 27, No. 6, pp. 329-336, ISSN 0166-2236

Lewis, J., McGowan, E., Rockwood, J., Melrose, H., Nacharaju, P., Van Slegtenhorst, M., Gwinn-Hardy, K., Paul Murphy, M., Baker, M., Yu, X., Duff, K., Hardy, J., Corral, A., Lin, W.L., Yen, S.H., Dickson, D.W., Davies, P. \& Hutton, M. (2000). Neurofibrillary tangles, amyotrophy and progressive motor disturbance in mice 
expressing mutant (P301L) tau protein. Nature Genetics, Vol. 25, No. 4, pp. 402-405, ISSN 1061-4036

Li, Q.M., Tep, C., Yune, T.Y., Zhou, X.Z., Uchida, T., Lu, K.P. \& Yoon, S.O. (2007). Opposite regulation of oligodendrocyte apoptosis by JNK3 and Pin1 after spinal cord injury. Journal of Neuroscience, Vol. 27, No. 31, pp. 8395-8404, ISSN 0270-6474

Lim, F., Hernandez, F., Lucas, J.J., Gomez-Ramos, P., Moran, M.A. \& Avila, J. (2001). FTDP17 mutations in tau transgenic mice provoke lysosomal abnormalities and Tau filaments in forebrain. Molecular and Cellular Neurosciences, Vol. 18, No. 6, pp. 702714, ISSN 1044-7431

Lim, J., Balastik, M., Lee, T.H., Nakamura, K., Liou, Y.C., Sun, A., Finn, G., Pastorino, L., Lee, V.M. \& Lu, K.P. (2008). Pin1 has opposite effects on wild-type and P301L tau stability and tauopathy. Journal of Clinical Investigation, Vol. 118, No. 5, pp. 18771889, ISSN 0021-9738

Lin, F.C. \& Arndt, K.T. (1995). The role of Saccharomyces cerevisiae type 2A phosphatase in the actin cytoskeleton and in entry into mitosis. EMBO Journal, Vol. 14, No. 12, pp. 2745-2759, ISSN 0261-4189

Lindwall, G. \& Cole, R.D. (1984). Phosphorylation affects the ability of tau protein to promote microtubule assembly. The Journal of Biological Chemistry, Vol. 259, No. 8, pp. 5301-5305, ISSN 0021-9258

Liou, Y.C., Sun, A., Ryo, A., Zhou, X.Z., Yu, Z.X., Huang, H.K., Uchida, T., Bronson, R., Bing, G., Li, X., Hunter, T. \& Lu, K.P. (2003). Role of the prolyl isomerase Pin1 in protecting against age-dependent neurodegeneration. Nature, Vol. 424, No. 6948, pp. 556-561, ISSN 0028-0836

Lu, K.P. (2004). Pinning down cell signaling, cancer and Alzheimer's disease. Trends in Biochemical Sciences, Vol. 29, No. 4, pp. 200-209, ISSN 0968-0004

Lu, K.P., Hanes, S.D. \& Hunter, T. (1996). A human peptidyl-prolyl isomerase essential for regulation of mitosis. Nature, Vol. 380, No. 6574, pp. 544-547, ISSN 0028-0836

Lu, K.P., Liou, Y.C. \& Vincent, I. (2003). Proline-directed phosphorylation and isomerization in mitotic regulation and in Alzheimer's Disease. Bioessays, Vol. 25, No. 2, pp. 174181, ISSN 0265-9247

Lu, K.P., Liou, Y.C. \& Zhou, X.Z. (2002). Pinning down proline-directed phosphorylation signaling. Trends in Cell Biology, Vol. 12, No. 4, pp. 164-172, ISSN 0962-8924

Lu, K.P. \& Zhou, X.Z. (2007). The prolyl isomerase PIN1: a pivotal new twist in phosphorylation signalling and disease. Nature Reviews Molecular Cell Biology, Vol. 8, No. 11, pp. 904-916, ISSN 1471-0072

Lu, P.J., Wulf, G., Zhou, X.Z., Davies, P. \& Lu, K.P. (1999a). The prolyl isomerase Pin1 restores the function of Alzheimer-associated phosphorylated tau protein. Nature, Vol. 399, No. 6738, pp. 784-788, ISSN 0028-0836

Lu, P.J., Zhou, X.Z., Shen, M. \& Lu, K.P. (1999b). Function of WW domains as phosphoserine- or phosphothreonine-binding modules. Science, Vol. 283, No. 5406, pp. 1325-1328, ISSN 0036-8075

Lucas, J.J., Hernandez, F., Gomez-Ramos, P., Moran, M.A., Hen, R. \& Avila, J. (2001). Decreased nuclear beta-catenin, tau hyperphosphorylation and neurodegeneration in GSK-3beta conditional transgenic mice. EMBO Journal, Vol. 20, No. 1-2, pp. 27-39, ISSN 0261-4189

Lummis, S.C., Beene, D.L., Lee, L.W., Lester, H.A., Broadhurst, R.W. \& Dougherty, D.A. (2005). Cis-trans isomerization at a proline opens the pore of a neurotransmittergated ion channel. Nature, Vol. 438, No. 7065, pp. 248-252, ISSN 0028-0836 
Ma, S.L., Tang, N.L., Tam, C.W., Cheong Lui, V.W., Lam, L.C., Chiu, H.F., Driver, J.A., Pastorino, L. \& Lu, K.P. (2010) A PIN1 polymorphism that prevents its suppression by AP4 associates with delayed onset of Alzheimer's disease. Neurobiology of Aging, ISSN 0197-4580

Mandelkow, E. (1999). Alzheimer's disease. The tangled tale of tau. Nature, Vol. 402, No. 6762, pp. 588-589, ISSN 0028-0836

Marchini, J., Cardon, L.R., Phillips, M.S. \& Donnelly, P. (2004). The effects of human population structure on large genetic association studies. Nature Genetics, Vol. 36, No. 5, pp. 512-517, ISSN 1061-4036

Matsuo, E.S., Shin, R.W., Billingsley, M.L., Van deVoorde, A., O'Connor, M., Trojanowski, J.Q. \& Lee, V.M. (1994). Biopsy-derived adult human brain tau is phosphorylated at many of the same sites as Alzheimer's disease paired helical filament tau. Neuron, Vol. 13, No. 4, pp. 989-1002, ISSN 0896-6273

Mattson, M.P. (2004). Pathways towards and away from Alzheimer's disease. Nature, Vol. 430, No. 7000, pp. 631-639, ISSN 0028-0836

Mawal-Dewan, M., Henley, J., Van de Voorde, A., Trojanowski, J.Q. \& Lee, V.M. (1994). The phosphorylation state of tau in the developing rat brain is regulated by phosphoprotein phosphatases. The Journal of Biological Chemistry, Vol. 269, No. 49, pp. 30981-30987, ISSN 0021-9258

Mazanetz, M.P. \& Fischer, P.M. (2007). Untangling tau hyperphosphorylation in drug design for neurodegenerative diseases. Nature Reviews Drug Discovery, Vol. 6, No. 6, pp. 464-479, ISSN 1474-1776

Nigg, E.A. (2001). Mitotic kinases as regulators of cell division and its checkpoints. Nature Reviews Molecular Cell Biology, Vol. 2, No. 1, pp. 21-32, ISSN 1471-0072

Nishimura, I., Yang, Y. \& Lu, B. (2004). PAR-1 kinase plays an initiator role in a temporally ordered phosphorylation process that confers tau toxicity in Drosophila. Cell, Vol. 116, No. 5, pp. 671-682, ISSN 0092-8674

Noble, W., Olm, V., Takata, K., Casey, E., Mary, O., Meyerson, J., Gaynor, K., LaFrancois, J., Wang, L., Kondo, T., Davies, P., Burns, M., Veeranna, Nixon, R., Dickson, D., Matsuoka, Y., Ahlijanian, M., Lau, L.F. \& Duff, K. (2003). Cdk5 is a key factor in tau aggregation and tangle formation in vivo. Neuron, Vol. 38, No. 4, pp. 555-565, ISSN 0896-6273

Nowotny, P., Bertelsen, S., Hinrichs, A.L., Kauwe, J.S., Mayo, K., Jacquart, S., Morris, J.C. \& Goate, A. (2007). Association studies between common variants in prolyl isomerase Pin1 and the risk for late-onset Alzheimer's disease. Neuroscience Letters, Vol. 419, No. 1, pp. 15-17, ISSN 0304-3940

Orlicky, S., Tang, X., Willems, A., Tyers, M. \& Sicheri, F. (2003). Structural basis for phosphodependent substrate selection and orientation by the SCFCdc4 ubiquitin ligase. Cell, Vol. 112, No. 2, pp. 243-256, ISSN 0092-8674

Pastorino, L., Sun, A., Lu, P.J., Zhou, X.Z., Balastik, M., Finn, G., Wulf, G., Lim, J., Li, S.H., Li, X., Xia, W., Nicholson, L.K. \& Lu, K.P. (2006). The prolyl isomerase Pin1 regulates amyloid precursor protein processing and amyloid-beta production. Nature, Vol. 440, No. 7083, pp. 528-534, ISSN 0028-0836

Pearson, R.C., Esiri, M.M., Hiorns, R.W., Wilcock, G.K. \& Powell, T.P. (1985). Anatomical correlates of the distribution of the pathological changes in the neocortex in Alzheimer disease. Proceedings of the National Academy of Sciences USA, Vol. 82, No. 13, pp. 4531-4534, ISSN 0027-8424 
Pelech, S.L. (1995). Networking with proline-directed protein kinases implicated in tau phosphorylation. Neurobiology of Aging, Vol. 16, No. 3, pp. 247-256; discussion pp. 257-261, ISSN 0197-4580

Petrucelli, L., Dickson, D., Kehoe, K., Taylor, J., Snyder, H., Grover, A., De Lucia, M., McGowan, E., Lewis, J., Prihar, G., Kim, J., Dillmann, W.H., Browne, S.E., Hall, A., Voellmy, R., Tsuboi, Y., Dawson, T.M., Wolozin, B., Hardy, J. \& Hutton, M. (2004). $\mathrm{CHIP}$ and Hsp70 regulate tau ubiquitination, degradation and aggregation. Human Molecular Genetics, Vol. 13, No. 7, pp. 703-714, ISSN 0964-6906

Phiel, C.J., Wilson, C.A., Lee, V.M. \& Klein, P.S. (2003). GSK-3alpha regulates production of Alzheimer's disease amyloid-beta peptides. Nature, Vol. 423, No. 6938, pp. 435-439, ISSN 0028-0836

Poppek, D., Keck, S., Ermak, G., Jung, T., Stolzing, A., Ullrich, O., Davies, K.J. \& Grune, T. (2006). Phosphorylation inhibits turnover of the tau protein by the proteasome: influence of RCAN1 and oxidative stress. Biochemical Journal, Vol. 400, No. 3, pp. 511-520, ISSN 0264-6021

Ramelot, T.A. \& Nicholson, L.K. (2001). Phosphorylation-induced structural changes in the amyloid precursor protein cytoplasmic tail detected by NMR. Journal of Molecular Biology, Vol. 307, No. 3, pp. 871-884, ISSN 0022-2836

Ranganathan, R., Lu, K.P., Hunter, T. \& Noel, J.P. (1997). Structural and functional analysis of the mitotic rotamase Pin1 suggests substrate recognition is phosphorylation dependent. Cell, Vol. 89, No. 6, pp. 875-886, ISSN 0092-8674

Sansom, M.S. \& Weinstein, H. (2000). Hinges, swivels and switches: the role of prolines in signalling via transmembrane alpha-helices. Trends in Pharmacological Sciences, Vol. 21, No. 11, pp. 445-451, ISSN 0165-6147

Schneider, A., Biernat, J., von Bergen, M., Mandelkow, E. \& Mandelkow, E.M. (1999). Phosphorylation that detaches tau protein from microtubules (Ser262, Ser214) also protects it against aggregation into Alzheimer paired helical filaments. Biochemistry, Vol. 38, No. 12, pp. 3549-3558, ISSN 0006-2960

Segat, L., Pontillo, A., Annoni, G., Trabattoni, D., Vergani, C., Clerici, M., Arosio, B. \& Crovella, S. (2007). PIN1 promoter polymorphisms are associated with Alzheimer's disease. Neurobiology of Aging, Vol. 28, No. 1, pp. 69-74, ISSN 0197-4580

Selkoe, D.J., Yamazaki, T., Citron, M., Podlisny, M.B., Koo, E.H., Teplow, D.B. \& Haass, C. (1996). The role of APP processing and trafficking pathways in the formation of amyloid beta-protein. Annals of the New York Academy of Sciences, Vol. 777, pp. 57-64, ISSN 1749-6632

Shen, Z.J., Esnault, S. \& Malter, J.S. (2005). The peptidyl-prolyl isomerase Pin1 regulates the stability of granulocyte-macrophage colony-stimulating factor mRNA in activated eosinophils. Nature Immunology, Vol. 6, No. 12, pp. 1280-1287, ISSN 1529-2908

Smet, C., Wieruszeski, J.M., Buee, L., Landrieu, I. \& Lippens, G. (2005). Regulation of Pin1 peptidyl-prolyl cis/trans isomerase activity by its WW binding module on a multiphosphorylated peptide of Tau protein. FEBS Letters, Vol. 579, No. 19, pp. 41594164, ISSN 0014-5793.

Sontag, E., Nunbhakdi-Craig, V., Bloom, G.S. \& Mumby, M.C. (1995). A novel pool of protein phosphatase $2 \mathrm{~A}$ is associated with microtubules and is regulated during the cell cycle. Journal of Cell Biology, Vol. 128, No. 6, pp. 1131-1144, ISSN 0021-9525

Sontag, E., Nunbhakdi-Craig, V., Lee, G., Bloom, G.S. \& Mumby, M.C. (1996). Regulation of the phosphorylation state and microtubule-binding activity of Tau by protein phosphatase 2A. Neuron, Vol. 17, No. 6, pp. 1201-1207, ISSN 0896-6273 
Stoothoff, W.H. \& Johnson, G.V. (2005). Tau phosphorylation: physiological and pathological consequences. Biochimica et Biophysica Acta, Vol. 1739, No. 2-3, pp. 280297, ISSN 0006-3002

Suizu, F., Ryo, A., Wulf, G., Lim, J. \& Lu, K.P. (2006). Pin1 regulates centrosome duplication, and its overexpression induces centrosome amplification, chromosome instability, and oncogenesis. Molecular and Cellular Biology, Vol. 26, No. 4, pp. 1463-1479, ISSN 0270-7306

Sultana, R., Boyd-Kimball, D., Poon, H.F., Cai, J., Pierce, W.M., Klein, J.B., Markesbery, W.R., Zhou, X.Z., Lu, K.P. \& Butterfield, D.A. (2006). Oxidative modification and downregulation of Pin1 in Alzheimer's disease hippocampus: A redox proteomics analysis. Neurobiology of Aging, Vol. 27, No. 7, pp. 918-925, ISSN 0197- 4580

Suzuki, T., Oishi, M., Marshak, D.R., Czernik, A.J., Nairn, A.C. \& Greengard, P. (1994). Cell cycle-dependent regulation of the phosphorylation and metabolism of the Alzheimer amyloid precursor protein. EMBO Journal, Vol. 13, No. 5, pp. 1114-1122, ISSN 0261-4189

Takei, Y., Teng, J., Harada, A. \& Hirokawa, N. (2000). Defects in axonal elongation and neuronal migration in mice with disrupted tau and map1b genes. Journal of Cell Biology, Vol. 150, No. 5, pp. 989-1000, ISSN 0021-9525

Tanemura, K., Murayama, M., Akagi, T., Hashikawa, T., Tominaga, T., Ichikawa, M., Yamaguchi, H. \& Takashima, A. (2002). Neurodegeneration with tau accumulation in a transgenic mouse expressing V337M human tau. Journal of Neuroscience, Vol. 22, No. 1, pp. 133-141, ISSN 0270-6474

Vincent, I., Jicha, G., Rosado, M. \& Dickson, D.W. (1997). Aberrant expression of mitotic cdc2/cyclin B1 kinase in degenerating neurons of Alzheimer's disease brain. Journal of Neuroscience, Vol. 17, No. 10, pp. 3588-3598, ISSN 0270-6474

Vincent, I., Rosado, M. \& Davies, P. (1996). Mitotic mechanisms in Alzheimer's disease? Journal of Cell Biology, Vol. 132, No. 3, pp. 413-425, ISSN 0021-9525

Weingarten, M.D., Lockwood, A.H., Hwo, S.Y. \& Kirschner, M.W. (1975). A protein factor essential for microtubule assembly. Proceedings of the National Academy of Sciences USA, Vol. 72, No. 5, pp. 1858-1862, ISSN 0027-8424

Weiwad, M., Kullertz, G., Schutkowski, M. \& Fischer, G. (2000). Evidence that the substrate backbone conformation is critical to phosphorylation by 42 MAP kinase. FEBS Letters, Vol. 478, No. 1-2, pp. 39-42, ISSN 0014-5793

Wells, N.J., Watanabe, N., Tokusumi, T., Jiang, W., Verdecia, M.A. \& Hunter, T. (1999). The C-terminal domain of the Cdc2 inhibitory kinase Myt1 interacts with Cdc2 complexes and is required for inhibition of $\mathrm{G}(2) / \mathrm{M}$ progression. Journal of Cell Science, Vol. 112 (Pt 19), pp. 3361-3371, ISSN 0021-9533

Wijsman, E.M., Daw, E.W., Yu, C.E., Payami, H., Steinbart, E.J., Nochlin, D., Conlon, E.M., Bird, T.D. \& Schellenberg, G.D. (2004). Evidence for a novel late-onset Alzheimer disease locus on chromosome 19p13.2. Amwrican Journal of Human Genetics, Vol. 75, No. 3, pp. 398-409, ISSN 0002-9297

Winkler, K.E., Swenson, K.I., Kornbluth, S. \& Means, A.R. (2000). Requirement of the prolyl isomerase Pin1 for the replication checkpoint. Science, Vol. 287, No. 5458, pp. 16441647, ISSN 0036-8075

Wulf, G., Finn, G., Suizu, F. \& Lu, K.P. (2005). Phosphorylation-specific prolyl isomerization: is there an underlying theme? Nature Cell Biology, Vol. 7, No. 5, pp. 435-441, ISSN 1097-6256 
Yaffe, M.B., Schutkowski, M., Shen, M., Zhou, X.Z., Stukenberg, P.T., Rahfeld, J.U., Xu, J., Kuang, J., Kirschner, M.W., Fischer, G., Cantley, L.C. \& Lu, K.P. (1997). Sequencespecific and phosphorylation-dependent proline isomerization: a potential mitotic regulatory mechanism. Science, Vol. 278, No. 5345, pp. 1957-1960, ISSN 0036-8075

Yang, Y. \& Herrup, K. (2007). Cell division in the CNS: protective response or lethal event in post-mitotic neurons? Biochimica et Biophysica Acta, Vol. 1772, No. 4, pp. 457-466, ISSN 0006-3002

Zheng-Fischhofer, Q., Biernat, J., Mandelkow, E.M., Illenberger, S., Godemann, R. \& Mandelkow, E. (1998). Sequential phosphorylation of Tau by glycogen synthase kinase-3beta and protein kinase A at Thr212 and Ser214 generates the Alzheimerspecific epitope of antibody AT100 and requires a paired-helical-filament-like conformation. European Journal of Biochemistry, Vol. 252, No. 3, pp. 542-552, ISSN 0014-2956

Zhou, X.Z., Kops, O., Werner, A., Lu, P.J., Shen, M., Stoller, G., Kullertz, G., Stark, M., Fischer, G. \& Lu, K.P. (2000). Pin1-dependent prolyl isomerization regulates dephosphorylation of Cdc25C and tau proteins. Molecular Cell, Vol. 6, No. 4, pp. 873-883, ISSN 1097-2765

Zhou, X.Z., Lu, P.J., Wulf, G. \& Lu, K.P. (1999). Phosphorylation-dependent prolyl isomerization: a novel signaling regulatory mechanism. Cellular and Molecular Life Sciences, Vol. 56, No. 9-10, pp. 788-806, ISSN 1420-682X

Zita, M.M., Marchionni, I., Bottos, E., Righi, M., Del Sal, G., Cherubini, E. \& Zacchi, P. (2007). Post-phosphorylation prolyl isomerisation of gephyrin represents a mechanism to modulate glycine receptors function. EMBO Journal, Vol. 26, No. 7, pp. 1761-1771, ISSN 0261-4189 


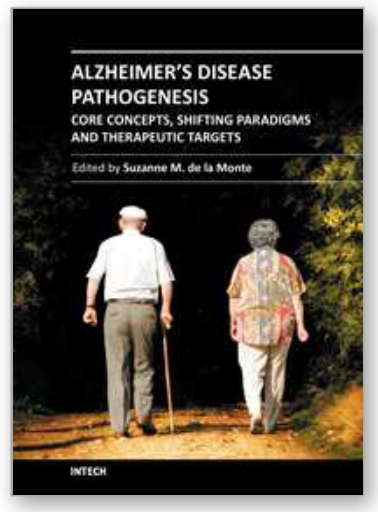

\author{
Alzheimer's Disease Pathogenesis-Core Concepts, Shifting \\ Paradigms and Therapeutic Targets \\ Edited by Dr. Suzanne De La Monte
}

ISBN 978-953-307-690-4

Hard cover, 686 pages

Publisher InTech

Published online 12, September, 2011

Published in print edition September, 2011

Alzheimer's Disease Pathogenesis: Core Concepts, Shifting Paradigms, and Therapeutic Targets, delivers the concepts embodied within its title. This exciting book presents the full array of theories about the causes of Alzheimer's, including fresh concepts that have gained ground among both professionals and the lay public. Acknowledged experts provide highly informative yet critical reviews of the factors that most likely contribute to Alzheimer's, including genetics, metabolic deficiencies, oxidative stress, and possibly environmental exposures. Evidence that Alzheimer's resembles a brain form of diabetes is discussed from different perspectives, ranging from disease mechanisms to therapeutics. This book is further energized by discussions of how neurotransmitter deficits, neuro-inflammation, and oxidative stress impair neuronal plasticity and contribute to Alzheimer's neurodegeneration. The diversity of topics presented in just the right depth will interest clinicians and researchers alike. This book inspires confidence that effective treatments could be developed based upon the expanding list of potential therapeutic targets.

\title{
How to reference
}

In order to correctly reference this scholarly work, feel free to copy and paste the following:

Kazuhiro Nakamura, Suk Ling Ma and Kun Ping Lu (2011). Pin1: A New Enzyme Pivotal for Protecting Against Alzheimer's Disease, Alzheimer's Disease Pathogenesis-Core Concepts, Shifting Paradigms and Therapeutic Targets, Dr. Suzanne De La Monte (Ed.), ISBN: 978-953-307-690-4, InTech, Available from: http://www.intechopen.com/books/alzheimer-s-disease-pathogenesis-core-concepts-shifting-paradigms-andtherapeutic-targets/pin1-a-new-enzyme-pivotal-for-protecting-against-alzheimer-s-disease

\section{INTECH}

open science | open minds

\section{InTech Europe}

University Campus STeP Ri

Slavka Krautzeka 83/A

51000 Rijeka, Croatia

Phone: +385 (51) 770447

Fax: +385 (51) 686166

www.intechopen.com

\section{InTech China}

Unit 405, Office Block, Hotel Equatorial Shanghai

No.65, Yan An Road (West), Shanghai, 200040, China 中国上海市延安西路65号上海国际贵都大饭店办公楼 405 单元

Phone: +86-21-62489820

Fax: +86-21-62489821 
(C) 2011 The Author(s). Licensee IntechOpen. This chapter is distributed under the terms of the Creative Commons Attribution-NonCommercialShareAlike-3.0 License, which permits use, distribution and reproduction for non-commercial purposes, provided the original is properly cited and derivative works building on this content are distributed under the same license. 